\title{
Peningkatan kemampuan membaca permulaan siswa kelas 1 SDN 01 Sengare melalui penggunaan media kartu kata
}

\author{
Ika Khaeriyah \\ SDN 01 Sengare, Kecamatan Talun Kabupaten Pekalongan
}

\begin{tabular}{l} 
Article Info \\
\hline Article history: \\
Received : 22 Juli 2021 \\
Revised : 2 September 2021 \\
Accepted : 20 September 2021
\end{tabular}

Keywords:

reading ability; media; word card; enhancement

\begin{abstract}
The research was designed in the form of classroom action research which was carried out in two cycles. Each cycle consists of stages of planning, implementation, observation, and reflection. Research data were collected through observation and tests at the end of each cycle. Based on the results of the research and discussion of classroom action research, it is shown that through the medium of word cards students' initial reading ability can be increased. This can be seen through the first cycle of completeness, it is known that 11 students who are declared complete with a percentage of $68.75 \%$ and students who do not complete as many as 5 people with a percentage of $31.25 \%$; with an average score of 69.5 . The percentage of completeness and the average value in the first cycle have not reached the indicators of research success so that it needs to be continued in the second cycle. The results of the second cycle showed students who completed 14 students with a classical completeness percentage of $87.5 \%$ with an average value of 90.5 . In addition, student activity during the learning process also increased from $70 \%$ in the first cycle to $85 \%$ in the second cycle. From the results obtained, the researcher concluded that word card media could improve the early reading ability of 1 st graders at SDN 01 Sengare.

ikakhaeriyah@gmail.com
\end{abstract}

(*) Corresponding Author:

How to Cite: Khaeriyah, I. (2021). Peningkatan kemampuan membaca permulaan siswa kelas 1 SDN 01 Sengare melalui penggunaan media kartu kata. Action Research Journal, 1(1): 53-58.

\section{PENDAHULUAN}

Keterampilan membaca dalam mata pelajaran Bahasa Indonesia merupakan salah satu keterampilan dasar berbahasa yang diajarkan di sekolah. Pengajaran membaca haruslah berisi usaha yang dapat membawa serangkaian keterampilan. Keterampilan tersebut erat hubungannya dengan proses yang mendasari pikiran semakin terampil seseorang berbahasa semakin cerdas dan jelas pula jalan pikirannya. Keterampilan membaca menjadi dasar utama dalam belajar, dengan membaca siswa akan memperoleh pengetahuan yang bermanfaat bagi pertumbuhan dan perkembangan daya nalar, sosial dan emosionalnya (Rumidjan, Sumanto, \& Badawi, 2017). Ada empat profil pembelajaran membaca di sekolah dasar yaitu: (1) menyimak sambil mambaca, dijelaskan isinya, menjawab soal, dan menceritakan isinya, (2) membaca judul, bergantian membacakan teks, mencari isi paragraph, menjawab pertanyaan, dan bergantian membacakan teks, (3) membaca keras bersama-sama, dijelaskan isinya, permainan kata, mencari pokok pikiran, mengerjakan latihan, dan mengarang berdasarkan gambar, dan (4) membaca dalam hati, berlatih bercerita, bercerita di depan kelas, dan menuliskan kembali isi cerita (Basuki, 2011; Rumidjan, Sumanto, \& Badawi, 2017).

Mengingat peranan membaca sangat penting bagi perkembangan siswa maka keterampilan membaca harus diajarkan sejak dini. Membaca hendaknya mempunyai tujuan, karena seorang yang membaca dengan suatu tujuan, cenderung lebih memahami dibandingkan dengan orang yang tidak mempunyai tujuan (Irdawati, Yunidar, \& Darmawan, 2014; Utami (2020). Membaca adalah suatu aktivitas komplek baik fisik maupun mental yang bertujuan 
memahami isi bacaan sesuai dengan tahap perkembangan kognitif siswa. Dalam membaca permulaan bertujuan untuk mendasari kemampuan membaca di tingkat yang lebih lanjut.

Siswa kelas 1 SDN 01 Sengare yang berjumlah 16 siswa, menunjukkan bahwa sebanyak 7 siswa atau 43,75\% siswa masih memiliki keterampilan membaca permulaan yang rendah. Hal tersebut dikarenakan oleh beberapa faktor, yaitu 1) siswa kurang aktif dalam kegiatan pembelajaran, kurangnya interaksi dengan guru, 2) pemilihan dan penggunaan metode pembelajaran yang kurang sesuai dan guru tidak menggunakan media sehingga pembelajaran cenderung terasa membosankan. Oleh karena itu, perlu digunakan media pembelajaran untuk meningkatkan kemampuan membaca permulaan siswa. Media pembelajaran menurut Khasanah \& Tumianto (2007) adalah setiap bahan, alat atau peristiwa yang dapat menciptakan kondisi yang memungkinkan pembelajar menerima pengetahuan, keterampilan, dan sikap sebagai sarana untuk mancapai tujuan. Media pembelajaran berfungsi mengarahkan siswa untuk memperoleh berbagai pengalaman belajar. Pengalaman belajar tergantung adanya interaksi siwa dengan media. Dengan penggunaan media yang tepat dan sesuai dengan tujuan pembelajaran, tentunya akan mempertinggi hasil belajar. Salah satu media yang dapat dibuat sendiri oleh guru adalah media kartu kata.

Media kartu kata ini bertujuan agar siswa lebih tertarik untuk membaca, karena dalam media kartu kata ini tersedia beberapa macam warna untuk menarik perhatian siswa. Selain itu media kartu kata ini sesuai dengan pembelajaran membaca permulaan (Rumidjan, Sumanto, \& Badawi, 2017). Media kartu kata yang dibuat oleh peneliti dapat meningkatkan semangat belajar siswa. Karena dalam pembelajarannya dilakukan dengan bermain. Pangastuti (2017) mengungkapkan bahwa kartu huruf adalah penggunaan sejumlah kartu sebagai alat bantu untuk belajar membaca dengan cara melihat dan mengingat bentuk huruf dan gambar yang disertai tulisan dari makna gambar pada kartu. Arsyad (2017) mengungkapkan bahwa kartu huruf adalah kartu abjad yang berisi gambar, huruf, tanda simbol, yang meningkatkan atau menuntun anak yang berhubungan dengan simbol-simbol tersebut. Kartu huruf adalah kartu kecil yang berisi gambar-gambar, teks atau simbol yang mengingatkan atau menuntun anak kepada sesuatu yang berhubungan dengan gambar itu, kartu huruf digunakan untuk melatih anak dalam mengeja dan memperkaya kosakata-kosakat baru (Arsyad, 2017). Penggunaan kartu huruf ini sangat menarik perhatian anak dan sangat mudah digunakan dalam pembelajaran membaca. Selain itu kartu huruf juga melatih kreatif anak dalam menyusun kata-kata sesuai dengan keinginannya (Rumidjan, Sumanto, \& Badawi, 2017).

Melalui permaianan menggunakan media kartu huruf anak-anak mampu memecahkan persoalan yang terkait dengan cara mengenal huruf, dengan permainan kartu huruf anak-anak dapat belajar dengan mudah tentang bentuk-bentuk huruf dan juga dapat mampu memahami dan memaknai simbol huruf dengan cara melihat gambar (Gading, Magta, \& Pebrianti, 2019). Permainan kartu huruf dapat memupuk sikap percaya diri kepada anak, karena anak distimulasi untuk berani dalam mecoba permainan kartu huruf. Kartu huruf memiliki peran dalam membantu memudahkan anak dalam pembelajaran kosakata bahasa Indonesia dan kemampuan membaca. Kartu huruf yang diperlihatkan kepada anak diharapkan dapat meningkatkan kemampuan berbahasa, menimbulkan sikap aktif dan dapat berkomunikasi di lingkungannya (Utami, 2020).

\section{METODE}

Penelitian ini dilaksanakan di kelas 1 SD Negeri 01 Sengare, Talun Kabupaten Pekalongan dengan jumlah siswa sebanyak 16 siswa. Keadaan fisik dan mental bagus (tidak ada cacat). Siswa kelas 1 berumur rata-rata antara enam tahun sampai tujuh tahun dengan karakteristik yang berbeda-beda dan lebih menyukai proses pembelajaran dengan metode bervariasi, tidak hanya di dalam ruangan kelas saja. Penelitian yang digunakan adalah penelitian tindakan kelas. Gambar 1 menjelaskan alur penelitian tindakan kelas secara umum dimulai dari perencanaan, pelaksanaan, pengamatan/observasi dan refleksi (Arikunto, 2010). 


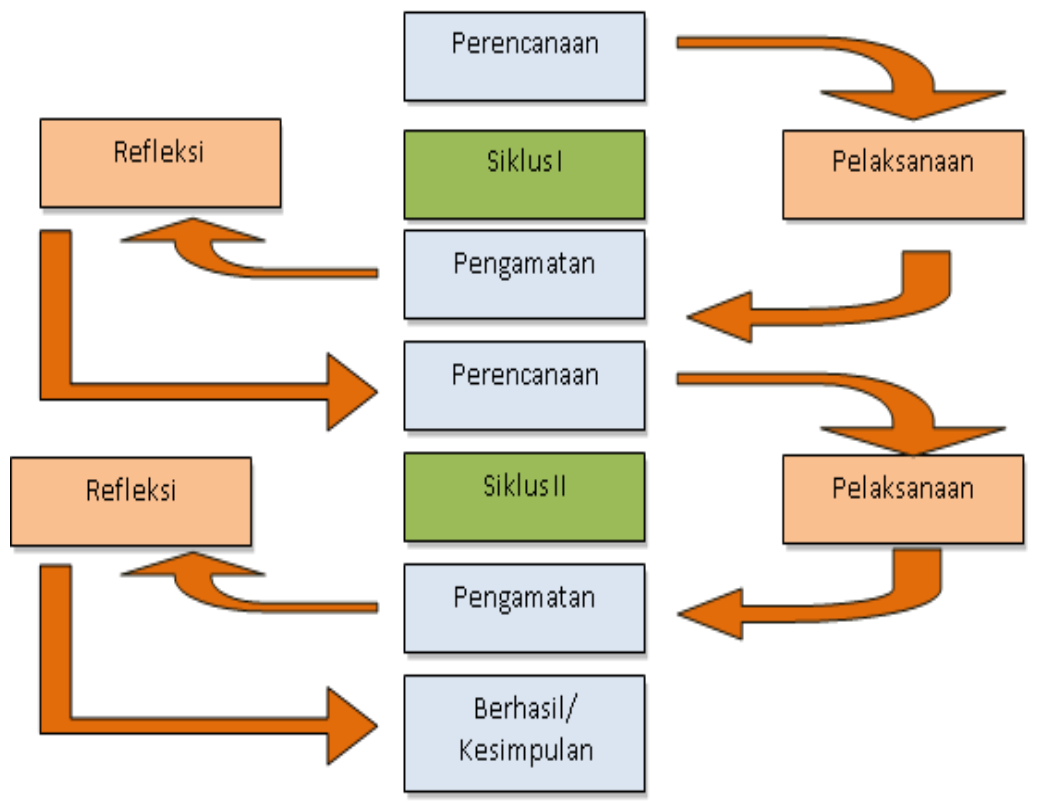

Gambar 1. Alur Penelitian Tindakan Kelas

Penelitian berfokus pada kemampuan membaca permulaan Siswa Kelas 1 SDN 01 Sengare melalui penggunaan media kartu kata. Teknik pengumpulan data penelitian menggunakan tes formatif di setiap akhir pembelajaran siklus, observasi untuk mengetahui keaktifan siswa selama proses pembelajaran. Analisis data yang digunakan dalam penelitian ini menggunakan teknik persentase. Indikator kinerja dalam penelitian ini adalah peningkatan kemampuan membaca permulaan yang dicapai siswa baik secara individu maupun klasikal. KKM untuk mapel ini adalah 70, jadi siswa dinyatakan tuntas belajar jika nilai yang diperoleh dalam ulangan harian 70 atau lebih. Kriteria yang digunakan untuk mengukur tingkat keberhasilan pembelajaran adalah sebagai berikut: 1) Kemampuan siswa dalam membaca permulaan dengan ketuntasan belajar individu mencapai $\geq 70$, dan ketuntasan belajar klasikal $\geq$ $85 \%$. 2) Kinerja guru meningkat dalam pembelajaran menggunakan media kartu huruf dengan kriteria baik dan mencapai prosentase $\geq 80 \%$, 3) Keaktifan siswa dalam mengikuti pembelajaran meningkat dengan kriteria tinggi dan mencapai persentase $\geq 75 \%$.

\section{HASIL DAN PEMBAHASAN}

Kartu huruf adalah kartu abjad yang berisi gambar, huruf, tanda simbol, yang meningkatkan atau menuntun anak yang berhubungan dengan simbol-simbol tersebut. Kartu huruf dapat merangsang anak belajar aktif, dapat melatih siswa dalam memecahkan persoalan, timbul pesaingan yang sehat dan akur antar anak, dan menumbuhkan sikap percaya diri kepada anak. Berdasarkan hasil tes dan pengamatan terhadap unjuk kerja siswa, yang meliputi kegiatan mengamati, menanya, mengumpulkan informasi, mengklasifikasi dan mengolah data, serta membuat kesimpulan, maka diperoleh hasil bahwa kemampuan membaca permulaan dan keaktifan siswa kelas 1 SD Negeri 01 Sengare dalam pembelajaran meningkat. Hal ini ditunjukkan dari hasil penelitian dari siklus I dan siklus II. Tabel 1 menunjukkan dengan jelas jumlah dan persentase ketuntasan belajar siswa yang merupakan representasi nilai dari kemampuan membaca permulaan siswa dalam pembelajaran siklus I dan siklus II. Nilai tersebut terus mengalami peningkatan dari siklus ke siklus. Hal ini ditunjukkan dari hasil analisis evaluasi pada siklus I dengan rata-rata kemampuan menulis siswa 69,5 dengan ketuntasan klasikal $68,75 \%$, sedangkan hasil analisis evaluasi siklus II diperoleh nilai rata-rata siswa 90,5 dengan ketuntasan klasikal 87,5\% sehingga indikator keberhasilan tercapai. 


\begin{tabular}{lccc}
\hline \multicolumn{4}{c}{ Tabel 1. Persentase Kemampuan } \\
\hline & Pra Siklus & Siklus I & Siklus II \\
\hline Jumlah Siswa Tuntas & 9 & 11 & 14 \\
Persentase Siswa Tuntas & $56,25 \%$ & $8,75 \%$ & $87,5 \%$ \\
Jumlah Siswa Tidak Tuntas & 7 & 5 & 2 \\
Persentase Siswa Tidak Tuntas & $43,75 \%$ & $31,25 \%$ & $12,5 \%$ \\
Rata-rata & 50 & 69,5 & 90,5 \\
\hline
\end{tabular}

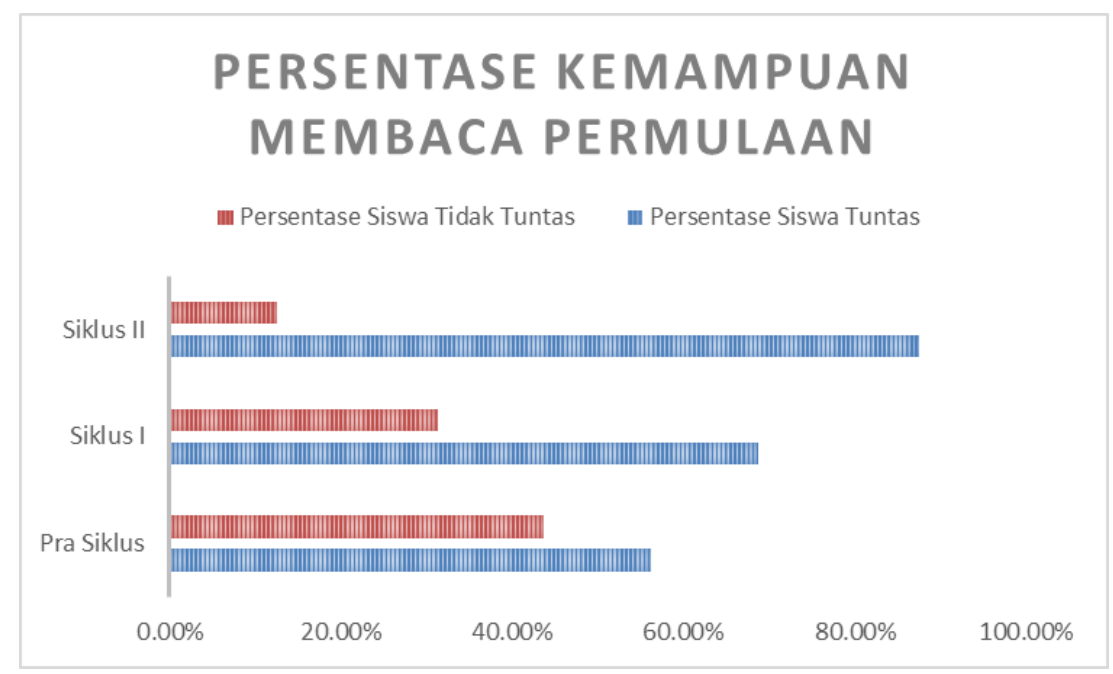

Gambar 2. Peningkatan Kemampuan Membaca Permulaan

Refeksi siklus I menyarankan bahwa penggunaan kartu huruf untuk meningkatkan membaca permulaan dalam penelitian harus dapat menciptakan situasi yang memungkinkan siswa lebih aktif dalam pembelajaran dan diberikan bimbingan. Namun kegiatan pembelajaran pada siklus I, masih ada juga siswa yang belum paham cara menggunakan membaca permulaan melalui kartu huruf dan pasif bertanya. Namun pada siklus II, proses pembelajaran berlangsung dengan baik dan hasil belajar siswa dapat meningkat. Hasil evaluasi siklus I, kemampuan siswa dalam membaca permualaan dinyatakan belum tuntas, sehingga harus dilanjutkan pada siklus II. Pada tabel di atas terlihat adanya peningkatan ketuntasan belajar klasikal sebesar 18,75\% dari siklus I jumlah siswa yang tuntas sebanyak 11 siswa menjadi 14 siswa yang tuntas pada siklus II. Rata - rata kelas juga mengalami peningkatan dari 69,5 pada siklus I meningkat menjadi 90,5 pada siklus II. Peningkatan ketuntasan belajar secara klasikal menunjukkan bahwa hasil refleksi dalam pelaksanaan tindakan siklus I telah dilakukan dalam pembelajaran siklus II. Permainan kartu huruf dapat memupuk sikap percaya diri kepada anak, karena anak distimulasi untuk berani dalam mecoba permainan kartu huruf. Kartu huruf memiliki peran dalam membantu memudahkan anak dalam pembelajaran kosakata bahasa Indonesia dan kemampuan membaca.

Dari hasil analisis peneliti dapat diketahui bahwa keaktifan siswa pada siklus I mencapai $70 \%$, meningkat jauh lebih baik dari sebelumnya (survei awal) yang kurang dari 50\%. Pada siklus II, keaktifan siswa meningkat menjadi $85 \%$ artinya jumlah siswa yang aktif bertambah 3 siswa. Dari hasil analisis di atas, maka dapat dikatakan bahwa tindakan yang dilakukan guru untuk meningkatkan keaktifan siswa berhasil. Hal ini membuktikan bahwa media kartu huruf memiliki peran dalam meningkatkan keaktifan siswa dalam proses belajar mengajar. Kartu huruf yang diperlihatkan kepada anak diharapkan dapat meningkatkan kemampuan berbahasa, menimbulkan sikap aktif dan dapat berkomunikasi di lingkungannya. Berikut disajikan Gambar 3 yang menunjukkan peningkatan persentase keaktifan pembelajaran dengan menggunakan media kartu huruf pada siswa kelas 1 SD Negeri 01 Sengare Kabupaten Pekalongan. 


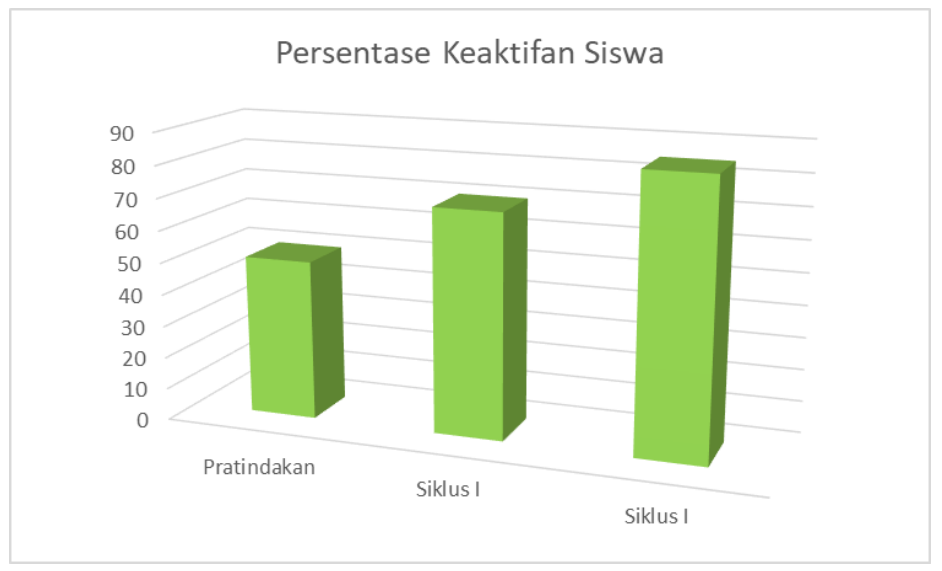

Gambar 3 Peningkatan Keaktifan Siswa

Hasil penelitian ini diperkuat oleh hasil penelitian yang dilakukan oleh Irdawati, Yunidar, \& Darmawan (2014) yang menjelaskan bahwa kemampuan membaca permulaan dapat ditingkatkan menggunakan media gambar kelas. Hasil penelitiannya menunjukkan bahwa ketuntasan siklus pertama diketahui bahwa siswa yang dinyatakan tuntas 19 orang dengan presentase $73,07 \%$ dengan nilai rata-rata 71,8 dan siswa yang tidak tuntas sebanyak 7 orang dengan presentase $26,9 \%$ dengan nilai rata-rata 12,3 presentase ketuntasan dan nilai rata-rata pada siklus pertama belum mencapai indikator ketuntasan yang dijadikan acuan dalam penelitian ini sehingga perlu dilanjutkan pada siklus kedua. Setelah dilkakukan siklus kedua diketahui bahwa siswa yang tuntas 26 orang siswa dengan presentase ketuntasan klasikal sebesar $100 \%$ dengan nilai rata-rata 92,3. Hasil penelitian Rumidjan, Sumanto, \& Badawi (2017) juga menjelaskan bahwa media kartu kata dapat digunakan sebagai salah satu alternatif pembelajaran pembelajaran bahasa Indonesia untuk melatih keterampilan membaca permulaan pada siswa kelas 1 SD. Hasil penelitian Utami (2020) juga menunjukkan bahwa penerapan media kartu huruf dapat meningkatkan kemampuan membaca siswa kelas I SD Negeri 1 Sumilir. Hasil penelitian tindakan kelas hasil observasi aktivitas guru siklus I diperoleh skor 3,13 dan siklus II diperoleh skor 3,25. Hasil observasi aktivitas siswa siklus I diperoleh persentase $70,8 \%$ dan siklus II diperoleh prosentase $78,25 \%$. Hasil nilai pemahaman siswa siklus I diperoleh rata-rata 69,16 ketuntasan 50\% dan siklus II menjadi 73,33 ketuntasan 75\%.

\section{SIMPULAN}

Berdasarkan hasil penelitian dan pembahasan peneliti ini maka dapat disimpulkan bahwa peningkatan kemampuan membaca permulaan menggunakan media kartu huruf dalam proses pembelajaran membaca pada siklus pertama yaitu $68,75 \%$ dalam proses pembelajaran membaca dan setelah melakukan siklus kedua terjadi peningkatan 18,75\% dalam kemampuan membaca permulaan menggunakan media kartu huruf dalam proses pembelajaran membaca. Ketuntasan klasikal pada siklus II mencapai $87,5 \%$ dan ada peningkatan belajar membaca siswa dengan rerata 90. Hal ini berarti media kartu huruf dapat meningkatkan kemampuan membaca permulaan siswa kelas 1 . Harapannya untuk lebih mengefektifkan peningkatan belajar membaca siswa, kiranya guru perlu mencari informasi lebih dalam tentang membaca permulaan dengan menggunakan media yang baik dan benar.

\section{DAFTAR PUSTAKA}

Arikunto, S. (2010). Metode penelitian. Jakarta: Rineka Cipta.

Arsyad, A. (2017). Media Pembelajaran. Depok: Putra Utama Offset.

Basuki, I. A. (2011). Profil Pembelajaran Membaca Pemahaman di Sekolah Dasar. Jurnal Sekolah Dasar. 20 (2). 
Gading, I. K., Magta, M., \& Pebrianti, F. (2019). Pengaruh metode suku kata dengan media kartu kata bergambar terhadap kemampuan membaca permulaan. Mimbar Ilmu, 24(3), 270276.

Irdawati, I., Yunidar, Y., \& Darmawan, D. (2014). Meningkatkan kemampuan membaca permulaan dengan menggunakan media gambar kelas 1 di MIN Buol. Jurnal Kreatif Online, 5(4).

Khasanah, N., \& Tumianto, D. (2007). Kamus besar bergambar bahasa indonesia untuk SD \& SMP. Jakarta: PT. Bina Sarana Pustaka.

Pangastuti, R., \& Hanum, S. F. (2017). Pengenalan abjad pada anak usia dini melalui media kartu huruf. Al-Hikmah: Indonesian Journal of Early Childhood Islamic Education, 1(1), 51-66.

Rumidjan, R., Sumanto, S., \& Badawi, A. (2017). Pengembangan media kartu kata untuk melatih keterampilan membaca permulaan pada siswa kelas 1 SD. Sekolah Dasar: Kajian Teori Dan Praktik Pendidikan, 26(1), 62-68.

Utami, D. B. (2020). Penerapan media kartu huruf untuk meningkatkan kemampuan membaca siswa kelas I SD Negeri 1 Sumilir Purbalingga tahun pelajaran 2020/2021. Jurnal Kualita Pendidikan, 1(3), 1-8. 